\title{
Sistem Penetapan Angka Kredit untuk Kenaikan Pangkat Guru di Lingkungan Pemerintah Kota Magelang Berbasis Web
}

\author{
Nugroho Agung Prabowo ${ }^{1}$, Nur Hidayah ${ }^{2}$ \\ ${ }^{1,2}$ Program Studi Teknik Informatika, FT, Universitas Muhammadiyah Magelang \\ Email: 'naprabowo@yahoo.com, ${ }^{1}$ nurh_84@yahoo.com
}

\begin{abstract}
Abstrak
Guru mempunyai hak kenaikan pangkat sesuai dengan angka kredit yang telah ditentukan. Penetapan angka kredit (PAK) guru dihitung berdasarkan Daftar Usul Penetapan Angka Kredit Guru (DUPAK) yang diusulkan oleh guru, yang kemudian di nilai dan di evaluasi oleh Tim Penilai. Perhitungan angka kredit baik dalam PAK maupun DUPAK masih menggunakan cara manual, sehingga baik guru maupun tim penilai harus menghitung setiap unsur angka kredit berdasarkan rumus yang telah ditentukan dengan cermat dan teliti. Untuk mengatasi masalah tersebut, dibangun suatu sistem penetapan angka kredit yang dapat membantu melakukan verifikasi dan validasi angka kredit yang diajukan oleh guru, sehingga proses perhitungan angka kredit menjadi cepat dan akurat. Sistem baru yang dibangun berbasis web, yang di dalamnya memuat semua unsur kegiatan yang dinilai angka kreditnya, setiap user memasukkan data, sistem secara otomatis akan melakukan perhitungan dan pengelolaan datanya terintegrasi sehingga tim penilai tidak perlu lagi melakukan entry data. Secara prosedur sistem lama dan sistem baru tidak jauh berbeda, perbedaan yang mendasar yaitu sistem yang baru menggunakan teknologi komputer berbasis web dalam pengelolaan datanya sehingga dapat mempersingkat proses entry data dan dapat mengatasi kendala dari sistem lama.
\end{abstract}

Kata Kunci: Angka Kredit, Penetapan Angka Kredit, DUPAK

\section{PENDAHULUAN}

Guru memperolah angka kredit setelah melalui proses penilian kinerja yang dilakukan oleh Kepala Sekolah/Pengawas sekolah. Angka kredit kumulatif yang harus dimiliki guru dalam proses promosi kenaikan pangkat/jabatan dihitung berdasarkan hasil penilaian terhadap beberapa unsur utama dan penunjang sesuai tugas dan beban kerja guru [1]. Penilaian angka kredit dilakukan oleh Tim Penilai angka kredit berdasarkan berkas pendukung yang diajukan oleh guru untuk mendapatkan nilai angka kredit, tim penilai angka kredit melakukan verifikasi terhadap bukti-bukti yang diterima dan menghitung angka kredit berdasarkan penilian kinerja guru.

Dalam perhitungan angka kredit, setiap unsur yang dinilai baik itu unsur utama maupun unsur penunjang, terbagi dalam sub unsur dimana masing-masing sub unsur tersebut mempunyai kriteria dan indikator, sehingga tim penilai harus menghitung setipa unsur berdasarkan rumus yang telah ditentukan. Banyaknya kriteria yang digunakan untuk proses penilaian angka kredit mengharuskan tim penilai untuk lebih cermat dan teliti sehingga dibutuhkan metode yang tepat.

Berdasarkan hal tersebut di atas dengan adanya sistem penetapan angka kredit guru, akan membantu untuk melakukan verifikasi dan validasi angka kredit yang di ajukan oleh guru, sehingga proses perhitungan angka kredit menjadi lebih cepat dan akurat $[5,6]$. 


\section{METODE}

\subsection{Lokasi}

Lokasi dalam perencanaan sistem dilakukan di Pemerintahan Kota Magelang khususnya di SKPD Dinas Pendidikan Kota Magelang. Lokasi dipilih karena sistem ini memang dispesifikasikan untuk memecahkan masalah dan membantu guru dalam membuat penetapan angka kredit untuk keperluan kepangkatan. Di wilayah kota Magelang memiliki jumlah guru sekitar 4000 personal sehingga dapat memudahkan dalam mengambil sample dengan tingkat penyebaran yang relatif homogen.

\subsection{Tahapan}

\subsubsection{Tahap Perancangan Sistem}

Pada tahap ini dibuat perancangan aplikasi Sistem dengan menggunakan aplikasi pemrograman yang berbasis web (web based). Sistem yang dirancangan ini nantinya akan dijadikan server utama dalam melayani sub server yang ada di masing-masing sekolah maupun untuk melayani baik secara admin maupun content kepada client.

\subsubsection{Tahap Perancangan}

Di lokasi tempat penelitian di wilayah Dinas Pendidikan Kota Magelang setelah di lakukan survei awal di masing-masing sekolah sudah memiliki server. Fasilitas tersebut adalah bekas dari proyek pengadaan jaringan Wide Area Network (WAN) kota tahun 2009 - 2010 yang sudah mangkrak semenjak tahun 2012 karena sistem tersebut sudah tidak mendapatkan dana operasional lagi dari APBD Kota Magelang. Jaringan eksisting tersebut nantinya akan di konfigurasi ulang (reconfiguration) sesuai dengan kebutuhan.

\subsubsection{Tahap Implementasi}

Tahap implementasi adalah tahap dimana aplikasi sistem yang telah dibuat bisa di integrasikan dengan jaringan WAN kemudian diakses di masing-masing sekolah dan client [2]. Tahapan ini diawali dengan pengujian aplikasi secara local hosting kemudian di instal di dalam server agar bisa di akses secara jaringan. Sosialisasi pengoperasian sistem dilakukan kepada para pengguna (guru) di tiap-tiap sekolah termasuk stakeholder pengawas dari Dinas Pendidikan Kota Magelang.

\section{HASIL DAN PEMBAHASAN}

\subsection{Analisa Sistem}

Dalam perhitungan angka kredit, terdapat 2 (dua) unsur yang dinilai, yaitu unsur utama dan unsur penunjang, dimana setiap unsur terbagi menjadi sub unsur. Bobot nilai untuk setiap sub unsur angka kredit guru sudah ditentukan berdasarkan Peraturan Menteri Pendidikan Nasional Nomor 35 Tahun 2010 tentang Petunjuk Teknis Pelaskanaan Jabatan Fungsional Guru dan Angka Kreditnya, khusus untuk penilaian angka kredit sub unsur pembelajaran/pembimbingan dan tugas tertentu dilakukan dengan menggunakan sistem paket [3]. Sistem paket tersebut menggunakan instrumen 
Penilaian Kinerja Guru sesuai dengan petunjuk teknik. Proses penilaian angka kredit guru dapat dilihat dalam flowchart seperti pada Gambar 1.

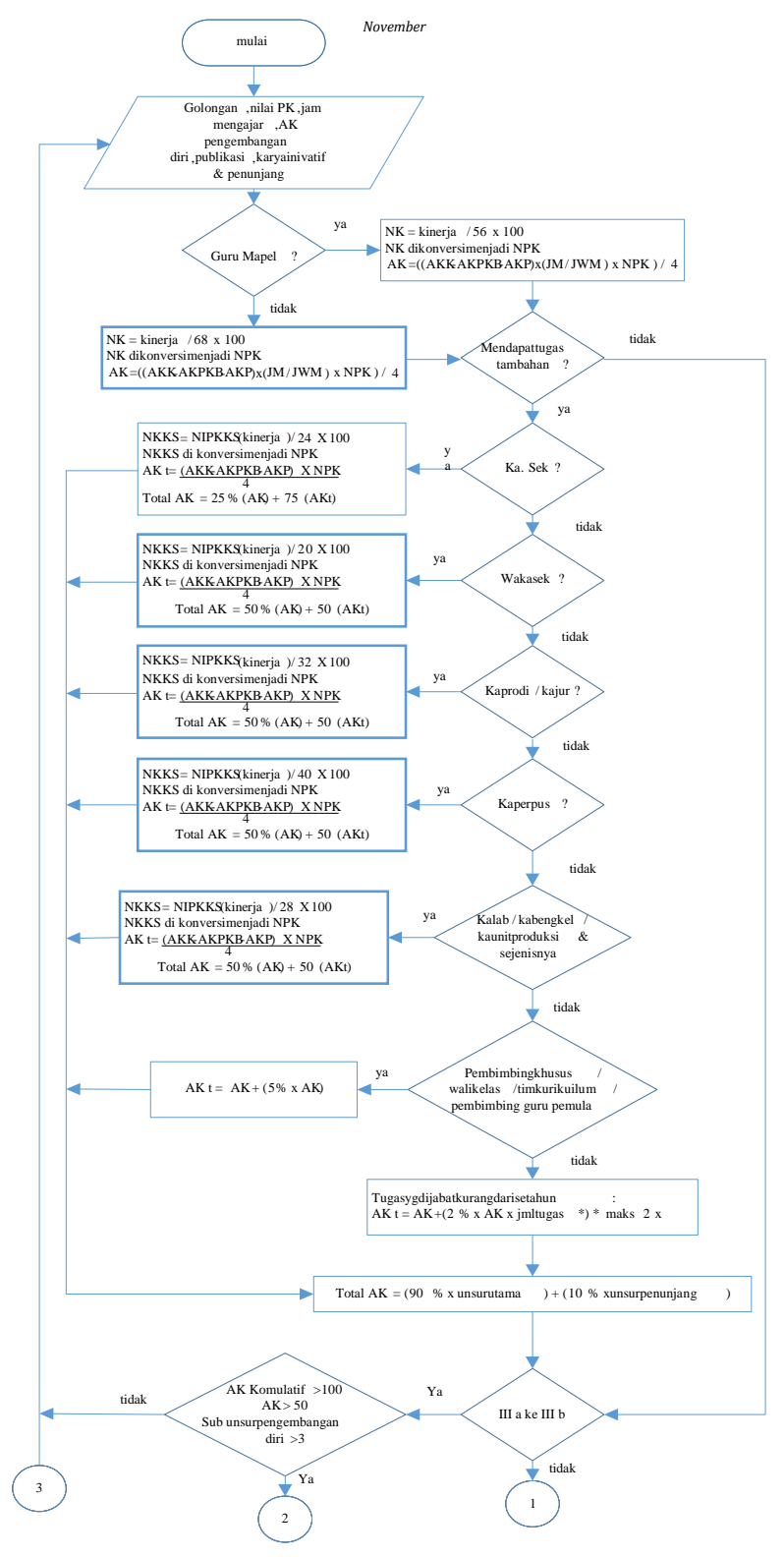




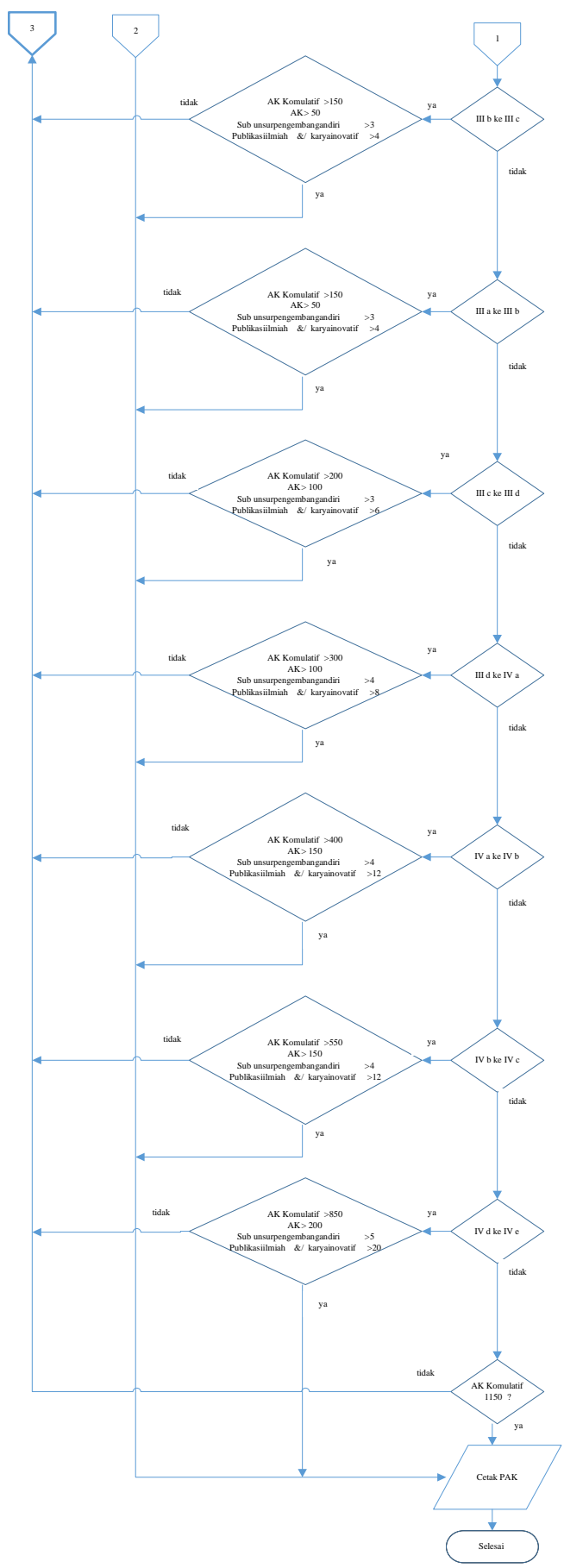

Gambar 1. Flowchart penilaian angka kredit 


\subsection{Perancangan Sistem}

1) Perancangan Arus Data

Dalam perancangan arus data, model yang digunakan adalah menggunakan Data Flow Diagram (DFD) [4]. DFD konteks sistem penetapan angka kredit ditunjukkan pada Gambar 2.

a. Diagram konteks

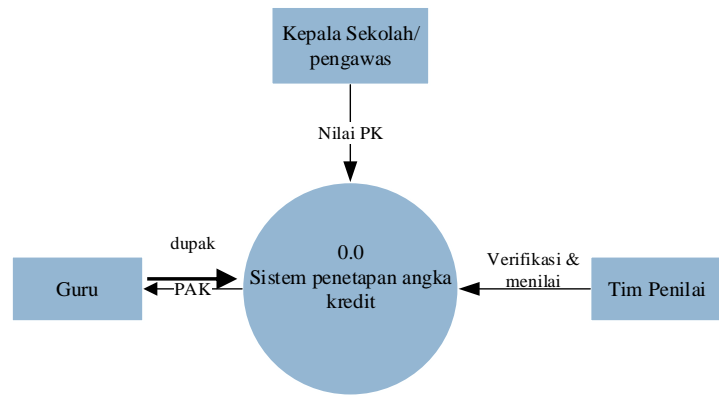

Gambar 2. DFD konteks sistem penetapan angka kredit

b. DFD level 0

DFD level 0 pada Gambar 3 menggambarkan proses penilaian angka kredit guru, dimulai dari input data guru sampai dengan laporan.

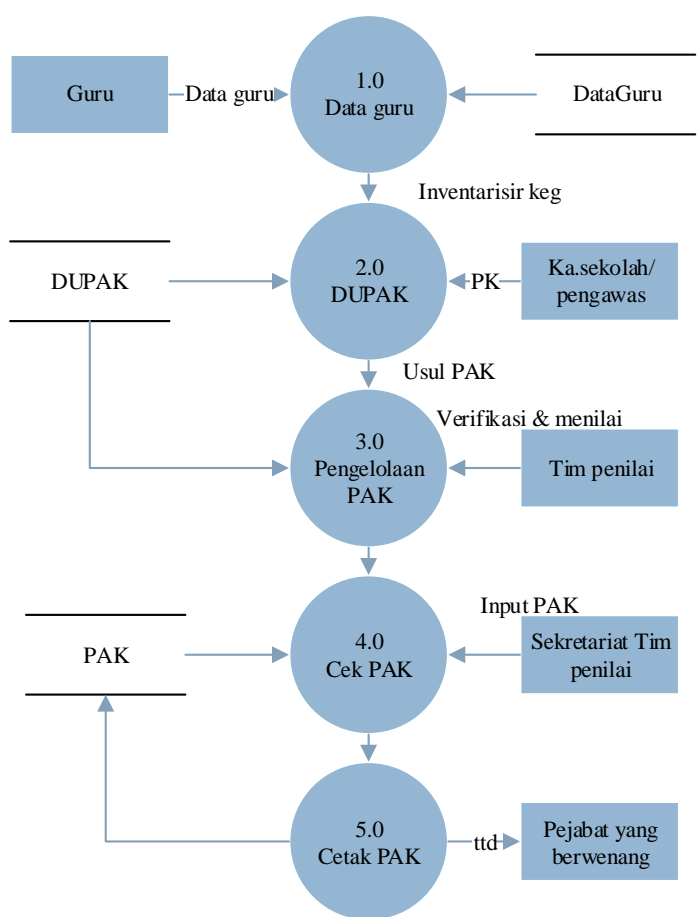

Gambar 3. DFD level 0 
2) Perancangan Basis Data

a. Entity Relationship Diagram (ERD)

ERD digunakan untuk menggambarkan relasi antar entitas yang ada pada sistem. ERD sistem penetapan angka kredit dapat dilihat pada Gambar 4.

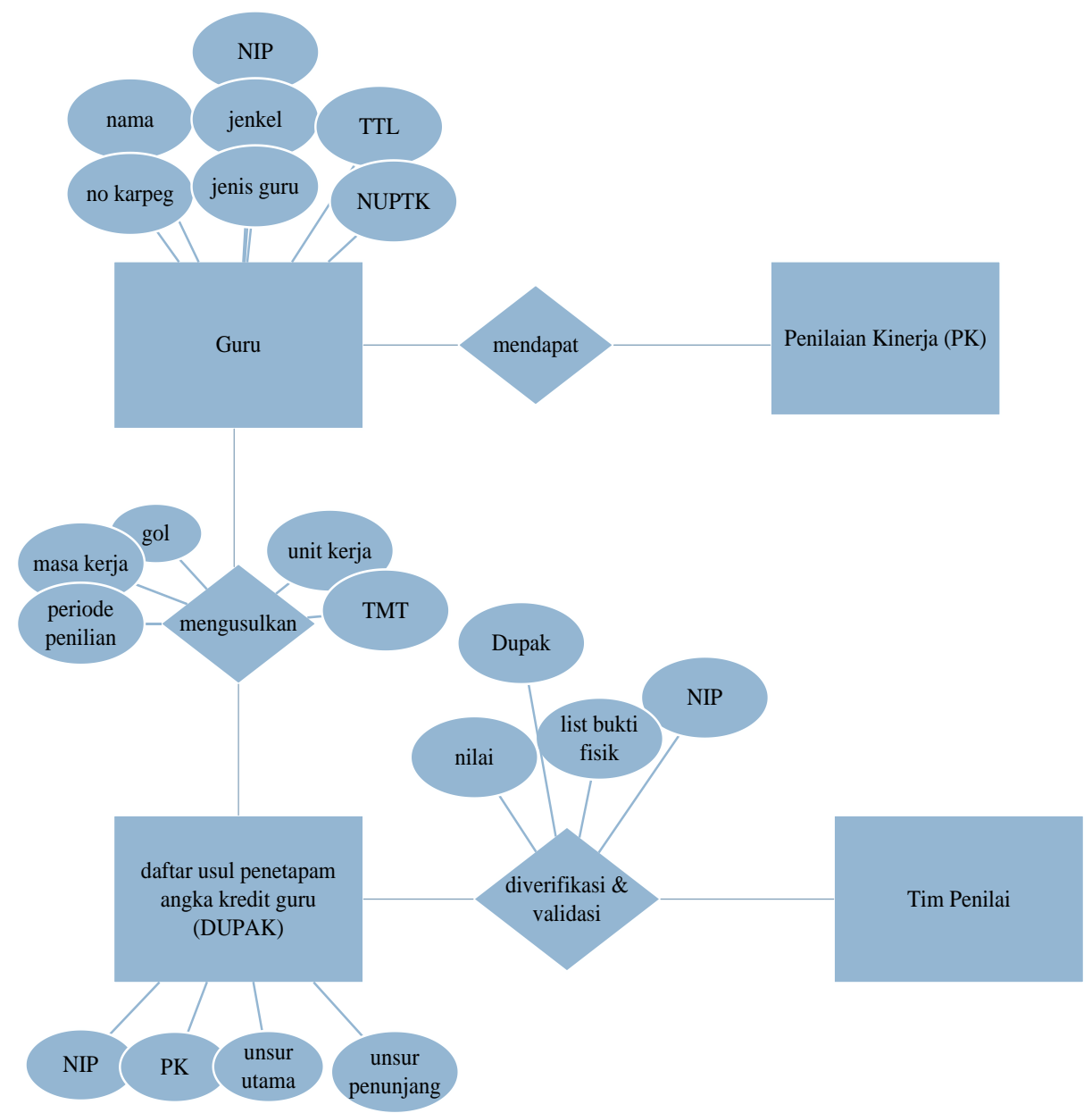

Gambar 4. Desain ERD 


\subsection{Implementasi Antar Muka}

Hasil program berupa antarmuka yang bisa digunakan oleh guru sebagai berikut.

1) Antar muka input angka kredit unsur pendidikan

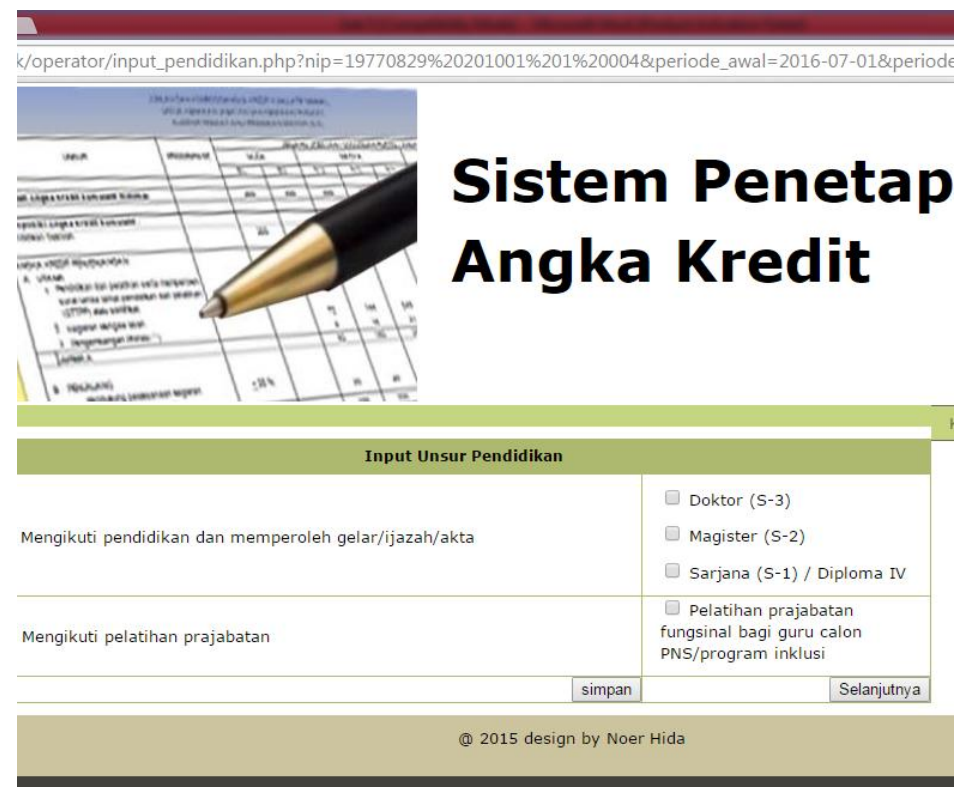

Gambar 5. Input angka kredit unsur pendidikan

2) Antar muka input angka kredit unsur pembelajaran

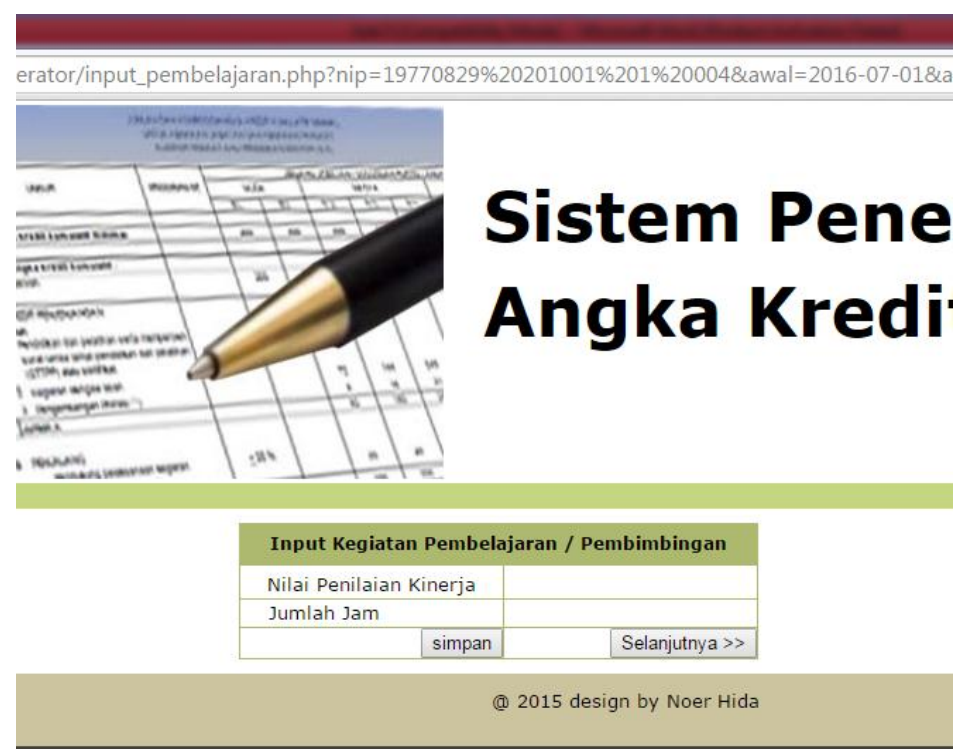

Gambar 6. Input angka kredit unsur pembelajaran 
3) Antar muka ouput

\begin{tabular}{|c|c|c|c|c|c|c|c|}
\hline & & & & $\begin{array}{r}\text { DA } \\
\text { PENETAPAN }\end{array}$ & $\begin{array}{l}\text { TAR USUL } \\
\text { NGKA KREDIT GURU } \\
\text { OMOR: }\end{array}$ & & \\
\hline Insta & si : SD & Jurang & bo: & & Masa penilaian mu & ly $2016 \mathrm{~s}$ & nber 2016 \\
\hline & KETER & NGAN & $2 O R_{R}$ & GAN & & & \\
\hline & 1 & $\mathrm{Nam}$ & & & Budi Santoso & & \\
\hline & 2 & NIP & & & 19770829201001 & & \\
\hline & 3 & NUPT & & & 79587446473000 & & \\
\hline & 4 & Nomo & erik & tu Pegawai & P. 588061 & & \\
\hline & 5 & Temp & $\tan$ & nggal Lahir & Magelang, 29 Aug & & \\
\hline & 6 & Jenis & amir & & Pria & & \\
\hline & 8 & Pangk & Golo & gan Ruang/TMT & Penata Muda / IIIa & & \\
\hline & 9 & Jabate & & & Guru Pertama & & \\
\hline & & Masa & & Lama & & & \\
\hline & 10 & Golong & & Baru & & & \\
\hline & 11 & Jenis & & & Guru Kelas & & \\
\hline & & Unit k & & & SD Jurangombo 1 & & \\
\hline & PENET & PAN AI & $\mathrm{AAK}$ & & LAMA & BARU & JUMLAH \\
\hline & $\mathrm{I}$ & UNS & UTA & & & & \\
\hline & & & & VDIDIKAN & & & \\
\hline & & A & 1) & $\begin{array}{l}\text { Mengikuti pendidikan dan } \\
\text { memperoleh gelar/ ijazah/akta }\end{array}$ & 100.00 & 0.00 & 100.00 \\
\hline & & & 2) & Mengikuti pelatihan prajabatan & 3.00 & 0 & 3 \\
\hline & & B & & nbelajaran dan Tugas Tertentu & 14.05 & 12.62 & 26.67 \\
\hline II & & & & gembangan Keprofesian Berkelanju & & & \\
\hline & & c & & Melaksanakan pengembangan diri & 0.00 & 0.15 & 0.15 \\
\hline & & & & Melaksanakan publikasi ilmiah & 0.00 & & 1.50 \\
\hline & & & & Melaksanakan karya inovatif & 0.00 & 0.00 & 0.00 \\
\hline & & JUML & IUN & R UTAMA & 117.05 & 14.27 & 131.32 \\
\hline & & UNS & $\overline{P E N}$ & JANG & & & \\
\hline & II & Pens & ing & gas Guru & 0.75 & 0.75 & 1.50 \\
\hline & & JUML & IUN & R PENUNJANG & 0.75 & 0.75 & 1.50 \\
\hline & JUML & H UNS & UTA & A DAN UNSUR PENUNJANG & 117.80 & 15.02 & 132.82 \\
\hline III & $\begin{array}{l}\text { TID/ } \\
2015\end{array}$ & $\begin{array}{l}\text { XAP } \\
07-01\end{array}$ & & TIMBANGKAN UNTUK DINAIKKAN D, & MM JABATAN & $\mathrm{IIIT} / \mathrm{Per}$ & $\begin{array}{ll}\text { I } & / \text { TMT }\end{array}$ \\
\hline
\end{tabular}

Gambar 7. Output PAK

\section{SIMPULAN}

Berdasarkan hasil analisa, implementasi, pengujian dan pembahasan tentang sistem penetapan angka kredit untuk kenaikan pangkat guru di lingkungan pemerintah kota magelang, maka dapat diambil kesimpulan yaitu terbangunnya suatu sistem penetapan angka kredit guru berbasi web yang sudah terotomatisasi dan terintegrasi yang dapat mempersingkat proses entry data sehingga dapat mengatasi kendala yang ada pada sistem lama, yaitu lamanya dan rumitnya perhitungan angka kredit yang masih menggunakan perhitungan secara manual.

\section{REFERENSI}

[1] Peraturan Menteri Pendayagunaan Aparatur Negara dan Reformasi Birokrasi (Permen PANRB) No. 16 Tahun 2009 tanggal 10 November 2009 tentang Jabatan Fungsional Guru dan Angka Kreditnya.

[2] Jr,Mcleod R. 1999. Sistem Informasi Manajemen. PT. Prehalindo: Jakarta.

[3] Peraturan Menteri Pendidikan Nasional Nomor 35 tahun 2010 Tentang Petunjuk Teknis Pelaksanaan Jabatan Fungsional Guru dan Angka Kreditnya.

[4] Harianto, H. 2002. Konsepdan Perancangan Database, cetakan VI. Andi Offset, Yogyakarta. 
[5] Yeni, M. 2013. Perancangan Sistem Informasi Usulan Penetapan Angka Kredit Guru Berbasis WEB (Studi Kasus Dinas Pendidikan KabupatenPesisir Selatan, Tersedia: http://ejournal.unp.ac.id/index.php/jptk/article/download/2666/2265 (di akses tanggal 18 September 2014).

[6] Tahta, N.A. 2011. Pengembangan Sistem Penilaian Angka Kredit Untuk Pengajuan Kenaikan Jabatan Fungsional Dosen Berbasis Web. Tersedia : http://repository.uinjkt.ac.id/dspace/handle/123456789/999 (di akses tanggal 18 September 2014). 
